\title{
ERGONOMICS - FUTURE PERSPECTIVES
}

\section{E.J. McCORMICK}

PURDUE UNIVERSITY

\section{OPSOMMING}

Ergonomika ('n sinoniem vir "human factors engineering") het reeds heelwat bygedra tot die doeltreffende funksionering van die mens, maar nuwe gesigspunte en toepassingsvelde sal in die toekoms nodig wees. 'n Fundamentele onderskeid word getref tussen die gebiede van toepassing en die fokus van beoefenaars van die ergonomika. Hoewel toepassings in die militêre en industriële sfere redelik suksesvol was, behoort ergonomiese beginsels ook op verbruikerswese, argitektuur, vervoer en ontspanning toegepas te word. Die grootste uitdaging in die toekoms sal egter wees om "lewenskwaliteit" te verbeter deur tevredenheid te verhoog en mense te help om doeltreffender te leef en in die proses hoër waardevlakke te handhaaf. In werksaktiwiteite was die hoofdoel tot dusver om werk te standaardiseer en te vereenvoudig, maar dit word al hoe noodsaakliker dat poste verruim en verryk moet word. Waarskynlik sal alle poste nie vir alle bekleërs volkome bevredigend gemaak kan word nie, maar dit sou tog nuttig wees om heelwat meer aandag aan die "humanisering" van werksaktiwiteite te gee.

We have a native expression in the United States, the expression being "hang-ups". This refers to the things that are of concern to an individual, that is, the things he worries about and hopefully does something about. One of my own "hang-ups" of the last couple of decades has been in connection with what we call human factors engineering, that is something like you people call ergonomics. Actually, both of these terms are sufficiently ambiguous that they can mean all things to all people, in much the fashion mentioned by the March Hare in Alice in Wonderland who said "One could use a word to mean what he wants it to mean".

There have been some articles and papers on this matter of semantics, and even summaries of the "content" of the research carried out in the United States under the rubic "human factors", compared with that carried out elsewhere under the rubic "ergonomics". The European emphasis, for example, has tended to be somewhat more physiologically orientated as contrasted with the emphasis in the States which has perhaps been somewhat more

\footnotetext{
* Opening address presented at the annual convention of the Psychological Institute of the Republic of South Africa, Rand Afrikaans University, Johannesburg, September 1975.
} 
psychological in nature. To add to the semantic confusion, I might say that in a single issue of the Human Factors Society Bulletin, one article referred to the fact that ergonomics is broader in content and connotation than its American counterpart, human factors engineering, whereas in another article three pages beyond a statement was made that the term ergonomics is viewed as being narrower in scope than human factors.

All of this quibbling about semantics, and what is or what is not covered under any given label, however, leaves me rather cold. Basically it seems to me that - semantics apart there is a very definite and definitive common denominator running through this whole varied spectrum of areas of research and application, specifically the common denominator of being concerned for the application of the behavioural and biological sciences to the benefit of human beings. In very general terms this amorphous domain deals with the application of technology to various aspects of our man-made world - aspects of technology that have something to do with human beings within this man-made world, such as the design of things people use, and their operational procedures. One would be hard pressed to identify any area of interdisciplinary concern that is focussed more on the human being and his interests and welfare than what has become known as ergonomics or human factors.

Let me begin by setting forth a three-stage definition of ergonomics:

1. The central theme of ergonomics relates to the consideration of human beings in the design of the man-made objects, facilities, and environments that people "use" in the various aspects of their lives.

2. The objectives of ergonomics in the design of these man-made objects, facilities and environments are twofold, as follows: (1) to enhance the functional effectiveness with which people can use them; and (2) to maintain or enhance certain desirable human values in the process (e.g., health, safety, and satisfaction); this second objective is essentially one of human welfare.

3. The central approach of ergonomics is the systemic application of relevant information about human characteristics and behaviour to the design of the manmade objects, facilities, and environments that people use.

Let me next recapitulate briefly the historical background of ergonomics. In one sense ergonomics goes back to the origins of man. From the earliest existing relics and artifacts of mankind it is evident that he has continually tried to develop tools, devices, procedures, and facilities of various kinds that would have two primary objectives. One of these was to 
achieve certain objectives (let us think of these as system objectives or requirements, such as chasing the bears away from the door, or beating one's wife). The other was to fulfil certain desirable human goals of his own (in terms of satisfaction, minimizing physical stresses and strain, protection from the elements, and so forth). Between the times of these early artifacts and the present century there have been numerous pieces of evidence to indicate that mankind has consistently tried to modify his environment and the things around it in such a fashion that these objectives might be better fulfilled. If this is the case, you might well ask why are people now - all of a sudden - interested in and concerned about what we call ergonomics?

The answer to this question, I believe, lies in the fact that something has been added to the brew in recent decades that argues for our concerted attention to this area of concern. The new ingredient to the brew is, in my opinion, the fact that the rate of development of technology has been such that the previous evolutionary processes of change no longer can serve adequately as the basis for the improvement in the devices and facilities and environments with which people are involved. Many of the hand tools in use today speak elequently of the effectiveness of this evolutionary process in the improvement of the design of such devices. But when we talk about flights to the moon, high speed aircraft, computer systems, communications systems, elaborate new designs of industrial equipment, underwater exploration, and so forth, we are dealing with items of physical equipment that people have never used before, and environments to which they have never been exposed. Thus, the previous evolutionary processes that resulted in the gradual improvement of things that people used and of their environment is inappropriate as one becomes concerned about new systems and new environments. The development of technology that has made these new items of equipment and environments possible then imposes the requirements upon those who design them to take the human being into account early during the design stage, rather than accepting the age-old process of evolution as the basis for the "improvement" of man's lot in life.

Taking another view of ergonomics, let us now ask ourselves this question: Who are the individuals who are concerned with ergonomics? These generally fall into two camps. In the one camp are those who are concerned with the actual design of the man-made features of our civilization, that is, the items of physical equipment and the facilities that people use and the environments in which they live. This camp includes various types of engineers, industrial designers, architects, city planners, and so forth. In the other camp are those who are concerned with the development or generation, through research, of knowledge and insight about human beings, towards the end that such knowledge and insight might be "applied" by 
those who actually design the things people use. Here we would think primarily of the sciences of psychology, biology, physiology, sociology, anthropology, and so forth. Actually the line between these two groups of people is fairly muddy, since many of the "appliers" become involved in the development of knowledge and insight via the scientific route, and in turn, some of the behavioural and biological scientists also sometimes become actively involved in the design of things that people use. At the same time, we should probably view the field as generally embracing these two broad groups of professionals and scientists.

As sort of a backdrop to our speculations about the future, let us now review briefly the primary areas of application of ergonomics to date. It is true that prior to World War II there had been some sporadic interest in certain European countries and the United States in various specific areas of what we have now come to call ergonomics.

However, it was not until World War II that there was any major concerted focussed concern for this area. This concern was precipitated rather dramatically during World War II by the experiences of the various military services in finding that certain new items of military equipment could not be operated or maintained effectively by military personnel. On the basis of a combination of one or two systematic studies, and of rather obvious observations, it was apparent that some such equipment was so complex that the human problems experienced in operation and maintenance could be attributed more to deficiencies in the design of equipment in terms of human considerations, than to improper selection or training of personnel as such. As a consequence the military services in the United States and Great Britain in particular developed crash programs to give increased attention to the redesign of new generations of equipment that would be more suitable for human use. Thus, the one factor that propelled ergonomics to the forefront, was the war itself, and over the intervening years since then considerable attention has been given to the ergonometric design of military equipment.

In the meantime, however, certain non-military items of an essentially hardware nature - especially those of a complex nature, were found to have deficiencies in design that could be blamed for human operational and maintenance problems. Thus, certain other kinds of items such as aircraft, electronic systems, communication systems, computers, and so forth have had the "benefit of clergy" to at least some extent in their design - directed toward improved operational and maintenance procedures. Overshadowing the application of human factors to such items of equipment in the years since World War II, however, have been the various space programs, such as those of the United States and the USSR. Although it must be acknowledged that very significant, marked strides have been achieved in the field of 
ergonomics since the war, the major thrust of these achievements had been primarily to fulfil system objectives, the central purpose being that of designing systems in such a fashion that they could be more effectively utilized by human beings. This represents the first of the twofold objectives I mentioned. We could cite some examples of these achievements: How else would people have gotten to the moon or joined up in space? How else would pilots of highspeed aircraft be able to control their vehicles? How else would it be possible for people to operate computers as efficiently as at present? How else might certain efficient postal services (if not our own) have been developed?

However, there has been less progress toward the second objective, the fulfilment of certain desirable human goals and values. We can see evidence of progress in reducing the physical requirements of some kinds of work and in improved safety, although not much progress in making work more satisfying or in enhancing the psychological "quality of life". I will return to this aspect a bit later.

Aside from this aspect let us speculate about the world presently about us from the ergonomics point of view. Such speculations would lead us to two conclusions. In the first place there is of course a tremendous amount of "catching-up" to do, especially in the case of many developing countries that have not as yet fully benefited from the past achievements of ergonomics. But aside from this "catching-up" aspect, we can see that there are many items of "unfinished" ergonomics business throughout all parts of the world. To date the primary areas of application include military equipment, electronics equipment, large physical systems, space travel, and so forth. But let us speculate about some of the other man-made objects and facilities that people use, items that have not as yet been designed with systematic attention to the ergonometric aspects. Some such things come immediately to mind, such as a whole spectrum of consumer products, such as household appliances, furniture, kitchen equipment, and other gadgets. The whole field of architectural design and city and community planning and development is almost a virgin area as far as ergonometric considerations are concerned. There are indeed some stirrings of interest on the part of architects, although these efforts have not been pursued very far. There are, for example, certain universities that are carrying out research and instruction in what is becoming known as architectural psychology, such as the University of Strathclyde in Scotland and the University of Utah in the United States. Although automobiles have had some attention from the ergonometric sidelines, such attention has been fairly modest and limited. This is also true of transportation systems generally, such as railway systems, subway systems, rapid-transit systems, and so forth. It 
seems to me the whole problem of moving people about the face of the earth, whether for local or long-distance travel purposes, is one that is thoroughly infested with human factors problems - as well as with engineering, economic, and political problems. This is particularly the case with the local transportation in metropolitan areas. What about the field of recreation? There have been many documented instances of injuries and, death from recreation equipment that has been poorly designed for the purpose, or inappropriately used. You people do not use many snowmobiles or ski's down here, but I might just mention that in Canada there have been a couple of studies dealing with both of these items of equipment from the personal safety point of view that point up the importance of ergonometric consideration in their design and operation. One could go from these kinds of items of recreation and sports equipment to virtually any others and immediately run into a host of ergonomic aspects that as yet have not been given systematic attention. The field of health care is one that is a very worrisome problem for many countries, and in part it seems that the efficiency with which such systems are provided, would depend on ergonomic principles and data. We could extend our inventory if we wish, into such areas as personal safety, the provision of public services by government agencies, the provision of educational services by educational institutions (such as by the use of computer aided instruction, programmed instruction, and so forth), the entertainment of people, police and fire protection provided by communities, the providing of news and communication services to people, oceanography, environmental design, increased attention to manufacturing and service processes, quality control, prosthetics, and some of the human problems that will emerge with increasing automation.

In general terms, then, it seems to me that there are some of the potential new content areas for ergonomics, most of these being already existing features of our civilization. In so saying, however, I am not saying that people who are interested in ergonomics will immediately jump into these with all four feet. Rather I am saying that I believe these are the potentially new content areas of ergonomic concern. As we all know, the bald facts of life hinge very frequently on money and political matters, and the limitations of money, and alltoo-frequent short-sighted political decisions, frequently impose roadblocks to improvement of human welfare. At the same time, I believe it is incumbent upon those who are generally "hung-up" on ergonomics to keep pressing their issue into these areas of potential application.

Back a while ago I mentioned two possible observations that one might make as he looked at the world as it exists today from the ergonomic point of view, one being the 
"catching-up" that is necessary for the so-called developing countries, and the other application of ergonomic principles and data to many existing man-made features of our civilisation. Let me shift to a consideration of the world of tomorrow. Obviously the outlines of the world of tomorrow are fairly ambiguous, but we can see looming ahead some of the kinds of problems that are likely to become dominant within the (unfortunately) not too distant future. Paramount among these is the matter of energy. The world demand for energy is going to require the development and production of new sources of energy, and regardless of what form these approaches might take they will have a significant impact upon the style of living, and the quality of life of people on the face of the earth. Whether this will be for the better or worse we can not say, although we hope it will be for the better. But this impact will probably influence the nature of the jobs many people will have, and the life styles of some (if not all) people. I have a strong suspicion that there are going to be some rather nasty ergonomic problems associated with such adjustments.

Another major problem that is looming up (and is in some degree already here) is that of pollution - of the air we breath, of the food we eat, of the lakes, rivers, and the oceans, and of the places we work. The ergonomists have been dealing with at least some environmental problems, and it is only natural to believe that they could make significant contribution to pollution control, insofar as the human aspects are involved. In addition, we could expect that whatever is done (or is not done) in the way of pollution control may affect the nature and quality of life. Hopefully, such pollution control will in and of itself bring some benefit, but in any event, the processes and problems associated with such control are going to necessitate changes in technology, and styles of living, and here again we could envision the possibility of some associated ergonomic problems.

Another change in the future that will be of concern to the ergonomic clans will be that related to the effects of future technological developments. The clouded crystal ball precludes the making of any very definitive predictions about what the future holds in terms of technological developments but we can predict with substantial certainty that there will be developments that we simply cannot now imagine - just as our ancestors could not predict that we would be watching TV, going to the moon, or talking to people on the other side of the earth. Just as technology of the past several decades has brought a host of ergonomic problems, so the future technological developments will bring their associated ergonomic problems (such as, for example, working in the depths of the ocean recovering metals and other materials). 
In a very general sense, then, it seems reasonable to believe that the areas of potential future concern of the ergonomic clans would include the following: 1. the "catching-up" that is necessary for the developing countries; 2. the application of ergonometric principles and data to many existing man-made features of our civilisation that have not as yet benefited from ergonomics; 3 . some of the problems associated with the development and use of new forms of energy; 4. pollution and pollution control; and 5. the implications of whatever future technology holds for us, either in the form of potential benefits to mankind, or the development of more diabolical means of doing away with ourselves.

But although these might be the primary areas of future involvement of ergonomics, (that is, the "content" areas of concern), there is, I believe, a potentially more dominant question about the future of ergonomics that we might ask, as follows:

What are the ergonomists going to do about these areas?

In reflecting about this we get back to what I said about the primary objectives of ergonomics, namely those of fulfilling desirable systems objectives or requirements, and those relating to the enhancement of human welfare. By all odds the primary concern of the ergonomists to date has dealt with the first of these, the design of facilities and systems in such a fashion that when human beings are involved in them, the system objectives and requirements are better fulfilled. But aside from some concern for human-related criteria such as safety and reduction of energy expenditure, the ergonomists of the world have given short shrift to other types of human goals, such as human satisfaction, the achievement of human values, and other admittedly subjective aspects of life. It is my own personal opinion that the primary challenges of the future to ergonomics lie in the direction of applying technology to the design of the man-made world in which we live toward the end of enhancing human satisfactions and of providing reasonable opportunity for the achievement of reasonable human values. We might view this possible concern as the "focus" of ergonomics as contrasted to the "content" areas mentioned before.

In general we can view this challenge in terms of two major thrusts. One of these is related to what we might refer to as the "quality of life", that is, the aspects of life that are somewhat separated from the jobs people have, and the other relates to the world of work itself, and the satisfactions people might gain from their work activities.

With respect to what I referred to as the quality of life, Dr. H. McIlvaine Parsons, the current president of the Society of Engineering Psychologists, has recently expressed himself as follows (1975): "In directing our attention to the technological world in which we live and 
work, Dr. Julien Christensen asked us not only to improve technology for human performance, but also to take a broader view of its impact on human behaviour and values.

"Further, if we really are interested in modern technology, at least in its design, procedures, and evaluation for human activities, shouldn't we embrace all of the man-made world? What about architecture? About computer software and its programming? About technology assessment by planners and economists? About analysis and training in accident prevention and safety programs?" In other words, he is making a case for ergonomics to become more concerned with the potential impact of technology on the total living environment - on the "quality of life" if you will. This is a frame of reference which I heartily endorse.

If the field of ergonomics expands into some of the areas we have mentioned (such as architecture, city and community planning, recreation, health services, etc.) the research investigators and practitioners in the field would almost of necessity be dealing with generally different types or classes of criteria than they have been dealing with in the past. As I said a few moments ago, the dominant type of criterion that has been used in the field of ergonomics to date has been essentially some indication or measure of system performance - that is, how well the combination of human beings and some piece of hardware performs a desirable system objective. But as one moves into the amorphous areas that one might think of as the "living environment", and the "quality of life", some of the criteria take on a very different hue. If one were to speculate about the possible relevant criteria related to the impact of technology on the general living environment, one would be concerned with such constructs as physical convenience, convenient mobility, physical comfort, the adequacy of personal space, opportunity for social interaction and/or for privacy, the fulfilment of aesthetic and personal values, and emotional health and welfare, along with the ubiquitous concern for financial aspects. Let us note that many of these criteria are of essentially a subjective nature, and thus do not lend themselves readily to objective measurement. Let us also be cognisant of the fact that with some of these kinds of criteria there could be wide - and valid - differences between and among individuals, such as in their aesthetic and personal values, the desirability of opportunity for social interaction, and so forth. Some of these areas of concern obviously are the same as the ones that the social psychologists and sociologists worry about; so here we find that the ergonomists (who typically deal with the hardware kinds of things in the manmade world we live in) and the social psychologists and sociologists (who deal with social interaction and the like - almost at the other end of the spectrum) - that these two groups of 
people might become bed fellows in some (hopefully) symbiotic relationship directed toward the creation of the man-made features of our civilisation for a variety of desirable human goals and objectives. Mind you, I am not saying the ergonomists will in fact cross this bridge to join forces with the social psychologists. Rather, I am saying that they should do so, and I hope in the long run they will bring to bear their expertise in design-related matters to an essentially social frame of reference, the man-made aspects of the world in which people live.

In addition to becoming interested in the implications of technology as it relates to the "quality of life", I believe the ergonomists also should become more concerned about the implications of what they do regarding the nature of human work, as this might affect the satisfactions people gain from their work. Just recently a couple of Czechoslovakian ergonomics experts (Xeleny and Matousek, 1975) made a plea for "humanising" human work, to "make work fit for humans". The impact of ergonomics on jobs and on job design is of course rather obvious, since the design of the equipment, machines, systems, and other facilities people use, and procedures for their use, virtually predetermine the nature of many jobs. By and large ergonomic efforts have tended toward making jobs simpler, so many, or most, people could perform the job activities. The basic thrust of ergonomics, then, has been one of simplification and standardisation of jobs.

The primary interests in "humanising" work, however, have not come from the ergonomists, but from the sociologists and social psychologists and what we call the organisational psychologists, and are reflected in what has variously come to be known as job enlargement or job enrichment. The major thrust of this effort is predicated upon the notion that jobs that are "enlarged" provide the opportunity for greater levels of job satisfaction than jobs that are - to coin a phrase "unenlarged". Thus, we have had two ongoing efforts over these past years, both of which have some impact upon the nature of the jobs people perform, each going its own merry way, relatively oblivious to the other, one tending toward job simplification, the other tending toward job enlargement. It seems to me that what appear to be generally disparate directions of these two areas do represent the two horns of a dilemma facing the human factors clan.

In trying to get some sort of perspective on the nature of this dilemma, I would like first to discuss each of these areas of effort separately in terms of the implications they may have on the kinds of human activities that are involved in the processes of production and use of the things you and I use in our daily lives. 
Let us start with a consideration of the ergonomics side of the coin. The roots of ergonomics spread out in various directions, but one of the tap roots goes back to the work of Frank Taylor and Gilbreth who were concerned with the "efficiency" of methods of work, leading to the development of industrial engineering and methods analysis. The central frame of reference of the ergonomics domain, in a sense, represents an elaboration and extension of the objectives of this tradition, but with particular emphasis on the design of the systems and facilities people use, toward the primary end of increasing the reliability and efficiency with which system goals are achieved. This frame of reference was especially dominant in the ergonomics discipline during the ancient and medieval periods of its history of the 1940's and 1950 's. By implication, this effort tended to result in the design of equipment and facilities that could be used by a broad spectrum of people. The term "idiot proofing" that surfaced during those years perhaps represents an exaggeration of this objective, but there are indeed grains of truth to this label. The intent in the design of at least many systems has been that of creating situations in which, given a particular stimulus, the responses of individuals were in effect pre-determined, thus producing little variability in resulting performance, and hopefully maximum efficiency.

By and large these tendencies resulted in the simplification of the activities of human beings in the operation of systems. And as pointed out by Hulin and Blood (1968), the process of job simplification results in jobs requiring less skill, which are more repetitive, and have less autonomy. There may also be differences in the types of human abilities required.

Now let me shift to a brief recap of the development that has become known as job enlargement or job enrichment. One of the first recognisable instances of this effort was that of a program initiated at the IBM Company, as reported by Walker in 1950. In general, however, this notion remained fairly dormant for several years. In the 1960's, however, there appeared various indications that a lot of people were pretty unhappy in their work. This recognition generated very substantial research and theorising about human motivation and job satisfaction, and probably a greater volume of opinion (as reflected in terms of numbers of words in the printed page).

A major focus of the current concern relating to worker motivation and job satisfaction is on the nature of the work activities of people, and it is here that the notion of job enlargement means many things to different people, including the modification of jobs in terms of such aspects as: determining one's own work pace, and to set one's own hours of work; quality control (serving as inspector for one's own work and correcting one's own 
mistakes); making setup and repairs; adopting one's own methods of work; adding more job activities in terms of number and variety (these can be more activities of the same general type, or can increase the scope of the job by having a person then follow through a complete job process from beginning to end); providing greater autonomy or control over one's job (and less supervision); assigning total responsibility for a particular operation to a work group who collectively make decisions about the operation; etc. We should recognise the fact that certain forms of job enlargement are quite unrelated to, or are in no way inhibited by, the physical equipment and facilities used in the work. I am thinking here of such aspects of the total job situation as work schedules, responsibility for inspection of one's own work, some aspects of group decision making, minimising supervision, work schedules (including setting one's own work schedule), job rotation and so forth. In our discussion today we should consider primarily those aspects of jobs that are predetermined by the nature of the physical systems and equipment people use, and that therefore serve as constraints on the nature of the job activities people have to perform.

Let me now get back to the dilemma I mentioned before, that revolves around the possible differences in the nature of human work as resulting from the traditional approach of the ergonomics discipline and that implied by job enlargement. The ergonomics approach is in part based on the assumption that "group mean" performance (i.e., the mean performance of groups of people using some system) will be improved if the tasks to be performed generally tend to be simple, easy, and standardised, thus in a sense reducing the skill level required to perform at an acceptable level. On the other hand, the job enlargement approach is based in part on the assumption that all individuals have essentially the same set of values that we all seek self-actualisation, and that this can be fulfilled through "involvement" in one's job, if the job is in fact one that offers such an opportunity. This increased involvement presumably would occur in the case of job situations in which there is increased responsibility and decision making, and increased use of one's skills. There is then sort of an implied expectation that people generally seek these kinds of job activities, and therefore the assumption that job enlargement is a universally good thing, like motherhood, love, peace, and so forth.

My naturally sceptical nature, however, cautions me against accepting this assumption lock-stock-and-barrel. In particular, there is one factor that generates my scepticism. This factor relates to the evidence and opinions about the effects of job enlargement. On the evidence side of the coin, it is probable that the results of most studies dealing with job 
enlargement efforts have resulted in increased job satisfaction on the part of many workers and usually some improvement in work performance (perhaps more typically improvements in quality than in productivity). However, although this has been a general pattern, it is by no means a universal pattern, and it is this that gives me pause. There have been job enlargement programs in which performance has not increased following job enlargement, or in which there has been no reported increase in job satisfaction. On the basis of a review of job enlargement research Hulin (1974) and Hulin and Blood (1968) conclude that the research evidence does not support the hypothesis that job size or job level is positively correlated in general with job satisfaction. On the basis of their reviews they conclude that the positive relationship between job size and job satisfaction cannot be assumed to be general, but rather depends to a great extent on the backgrounds of the workers in question.

On the opinion side of the coin, there are those who view job enlargement as the panacea for all the ailments of human work, and - to exaggerate a bit - imply that if all jobs would be enlarged, everyone would be happy in their work. This point of view is very strongly set forth in the book Work in America, and is promoted by Herzberg (1968), Argyris (1957), and Whyte (1955) as well as others.

On the other hand, there are those who take a somewhat more jaundiced view of this effort. For example, MacKinney et.al. (1962) state: " ... the fact of individual differences ... is a central fact of life in the behavioural sciences and yet would-be reformers apparently believe that all people must react in exactly the same way to the same job. The observer says to himself that job would drive me nuts in half an hour. From this he somehow concludes that it must drive everyone else nuts as well. This simply is not so! (For that matter, it's highly probable that many of the workers interviewed by sympathetic social scientists privately regarded their questioners' activities as a pretty terrible way to earn a living too.)

In connection with the fact of individual differences, I have been very much disturbed by the tendency on the part of some individuals to attribute subjective values to jobs when in fact they are the attributes of the people on the jobs. For example, there is a reference in one source (Work in America) to "dull, repetitive, seemingly meaningless tasks, offering no challenge or economy." There is no job or task that is intrinsically dull or meaningless or lacking in challenge. These are reactions of the individuals to their jobs, and are not attributes of the jobs themselves. Incidentally, I believe there are the seeds of the self-fulfilling prophecy in describing jobs as "dull, meaningless, and boring." If we keep telling people that their jobs are dull, boring, and meaningless, there may be a tendency for them to believe us! 
Obviously both sides cannot have a monopoly on "truth". In discussing this issue, Lawler (1969) offers what seems to be a reasonable theoretical frame of reference. He expresses the notion that job content can have a positive influence on motivation and performance to the extent that the job content provides for the reception - to the job incumbent - of what he calls "intrinsically rewarding outcomes".

He suggests (1973) that the difference in the reactions of people to enlarged jobs would be attributed to the strength of their "higher-order" needs - those people who get their "kicks" out of what he refers to as "intrinsic" outcomes such as feelings of achievement, growth, and competence. However, those people who do not have strong "higher-order" needs might not get their "jollies" out of enlarged jobs that people tell them they should receive. I am reminded of the wife on a camping expedition with her husband, cleaning the fish he caught, cooking them, washing the dishes - all the while battling the hungry mosquitoes - who said to her husband: "Tell me again how much fun this is." Even our own everyday experience would lead us to conclude that some people thrive on types of tasks and responsibilities that might drive other people up the wall.

We cannot today resolve the job enlargement issue, but let me restate my admittedly gut feelings about job enlargement. To begin with - and discounting the faddish aspects and the zealousness of the true "believers" - there is no question but that, by and large, job enlargement efforts should be chalked up on the positive side of the ledger. To the extent that jobs can be modified in the indicated directions, one would expect that enlarged jobs would make life more worthwhile (or less unworthwhile) for many - but not necessarily all - people, and that it might be accompanied by improved work performance. But I think job enlargement is not for everybody - because of individual differences - the widespread job enlargement of jobs (even if possible) would not result in everybody having a job that would be completely enthralling to him (or to her). I believe individual differences in prevailing attitudes toward (or interests in) job activities and/or toward things in general comprise a significant factor in the job satisfaction equation. (By implication, one might assume that there are some people who are so allergic to work in general that it would take Solomon to figure out what jobs would make them happy in their work.)

But the probability that job enlargement is not a universal cure for the blue-collar blues, or the white-collar blues, should not lead us to the conclusion that we should not worry about it. I believe that the ergonomics discipline has functioned for many years with a set of blinders that has made us quite oblivious to any appreciable concern for the implications of 
any efforts as related to the satisfaction people might receive from their work activities. In very general terms, I suppose I am arguing here for the removal of such blinders.

In this regard, there are at least a few straws in the wind to indicate that there is an undercurrent of concern on the part of the ergonomics discipline - perhaps a gnawing sense of unease - that hopefully will increase to more epidemic proportions. For example, Christensen in his address to Division 19 of the APA on "Limitless Man" (1973) expressed this concern. Lomov, in his very recent address to the International Congress of Applied Psychology (1974) spoke of the design of "activities" of people. The July issue of the Human Factors Society Bulletin has a boiled down version of the paper by Bittel on "Trends in the Design of Work" (1974), the central theme of which was the same as that which we are discussing today. And Chapanis in an invited talk at an international symposium on ergonomics in Bucharest this past year (1974) expressed his unease about this issue.

Getting back to the central theme of future perspectives regarding ergonomics, we can perhaps differentiate very generally between the potential future areas of application of ergonomics on the one hand, and what we might call the focus of concern on the other hand. As I indicated a while ago, many of the areas of future application are probably reasonably obvious. These include architectural design, community and city planning, transportation systems, health services, personal safety, law enforcement, underwater exploration, new energy sources, and pollution. In addition, of course, the ergonomics professions need consistently to be attuned to possible new technological developments that will have human factor implications. It is the major focus of ergonomics that I believe is the potentially more challenging aspect for the future. True, ergonomists must continue to be concerned with criteria of system objectives, designing systems for efficient use by people. But I believe that more importantly, they need to add an additional frame of reference, particularly as they move into certain different and new areas of application. That new frame of reference is that - over and above the fulfilment of system objectives - one should become more concerned in the design of our man-made world with the objective of reasonable human values and satisfactions. Operationally, such concern seems to break down into two primary areas. The first of these deals with the application of technology to the living environment of people toward the end of improving the quality of life. The second of these deals with the application of technology to the design of human work toward the end of "humanising" the nature of human work and providing increased opportunity for people to gain some reasonable satisfactions from their involvement in the production of the goods and services of the economy. 
This is a particular thorny issue because of the fact of individual differences, since different people gain satisfaction from different kinds of job activities. This particular aspect of the challenge of job design, then, is that of providing jobs which, on an across-the-board basis, would be of reasonable interest to people with various values and goals.

In talking about this shift in focus, I am not saying that ergonomists will naturally tend to add this focus to their basic research and applications. Rather, I think I am saying that this is what they should do. It behooves the leaders of this field to provide the guidance and the "nudging" to "encourage" the ergonomic disciplines to shift their gears in this direction, toward the long range enhancement of human welfare.

\section{SUMMARY}

Ergonomics (a synonym for human factors engineering) has contributed significantly to fundamental effectiveness of people, but needs a new emphasis and wider applications in future. A basic distinction is drawn between the areas of application and the focus of ergonomists. Although applications have been relatively successful in the military and industrial fields, ergonomics should also be applied to consumer products, architecture, transportation and recreation. In future, the primary challenge will be to improve the "quality of life" by enhancing human satisfaction and allowing people to function at higher value levels. In work activities the basic task of ergonomics has been to simplify and standardise jobs, but future focus should be on enlargement and enrichment of jobs. Because of individual differences probably not all jobs could be made completely satisfactory to all workers. However, significant contributions could be made through continued efforts to "humanise" work activities.

\section{REFERENCES}

Argyris, C. Personality and Organizations. New York: Harper, 1957.

Bittel, L.R. Trends in the design of work. Human Factors Society Bulletin, July 1974, 17(7), $1-2$.

Clapanis, A. What does ergonomics have to do with job satisfaction? Paper presented at internation symposium on ergonomics, Bucharest, September 1974.

Olristensen, J.M. Limitless man. Presidential address, Annual Meeting of the Division of Military Psychology, American Psychological Association, Montreal, September 1973. 
Herzberg, F. One more time: How do you motivate employees? Harvard Business Review, January-February, 1968, 46(1), 53-63.

Hulin, C.L., and Blood, M.R. Job enlargement, individual differences, and worker responses. Psychological Bulletin, 1968, 68(1),41-45.

Lawler, E.E. III. Job design and employee motivation, Personnel Psychology, 1969, 22, 426435.

Lawler, E.E. III. What do employees really want? Paper presented at the Annual Meeting of the American Psychological Association, Montreal, September 1973.

Lomor, B. F. Invited address International Congress of Applied Psychology, Montreal, 28 July to 4 August, 1974.

MacKinney, A.C., Wernimont, P.F., and Galitz, W.O. Has specialization reduced job satisfaction? Personnel, 1962, 39(1), 8-17.

Parsons, H.M. Human Factors Society Bulletin, 1975, 18(8).

Walker, C.R. The problem of the repetitive job. Harvard Business Review, 1950, 28(3), 5458.

Whyte, W.F. Money and Motivation; An Analysis of Incentives in Industry. New York: Harper, 1955.

Work in America. Report of a Special Task Force to the Secretary of Health, Education and Welfare. Cambridge, Mass.: The MIT Press, 1973.

Xeleny and Matousek, cited in Human Factors Society Bulletin, 1975, 18 (8). 